\title{
Relationships among Environmental Literacy, Locus of Control, and Future Orientation of STEM Students in the Philippines
}

\author{
Princes Raymunda G. Gatan ${ }^{1 *}$, Rosanelia T. Yangco², Sheryl Lyn C. Monterola²
}

\author{
${ }^{1}$ National Institute for Science and Mathematics Education Development, University of the Philippines, PHILIPPINES \\ 2 College of Education, University of the Philippines, PHILIPPINES \\ *Corresponding Author: pggatan@up.edu.ph
}

Citation: Gatan, P. R. G., Yangco, R. T., \& Monterola, S. L. C. (2021). Relationships among environmental literacy, locus of control, and future orientation of STEM students in the Philippines. Interdisciplinary Journal of Environmental and Science Education, 17(4), e2250. https://doi.org/10.21601/ijese/10984

\begin{tabular}{|c|c|}
\hline ARTICLE INFO & ABSTRACT \\
\hline $\begin{array}{l}\text { Received: } \\
29 \text { October } 2020\end{array}$ & $\begin{array}{l}\text { This study reports on the status and correlations among environmental literacy (EL), locus of control } \\
\text { (LOC), and future orientation (FO) of STEM students (N = 512). The EL results showed a low rate of } \\
\text { students' Environmental Knowledge but high Environmental Skills. The LOC results revealed that } \\
\text { students believed that they could best create environmental impacts through recycling yet least by } \\
\text { advocating on the environment. They were also more inclined to considering distant outcomes or } \\
\text { consequences of their actions rather than focusing on their immediate needs. The STEM students' } \\
\text { academic background, convenience, and personal benefit among others might have contributed to } \\
\text { correlation results of EL, LOC, and FO reported in this study. It is suggested that ample opportunities } \\
\text { be given to students to improve their EL. This may include going beyond environmental theories and } \\
\text { engaging students in authentic experiences to provide them with active roles in learning } \\
\text { environmental topics. Moreover, these topics should not only be consistently integrated among the } \\
\text { fields of sciences but also in other subjects making them interdisciplinary, meaningful, and relatable. }\end{array}$ \\
\hline & $\begin{array}{l}\text { Keywords: environmental literacy, environmental locus of control, future orientation, stem students, } \\
\text { gender difference in stem, environmental education }\end{array}$ \\
\hline
\end{tabular}

\section{INTRODUCTION}

Humans have impacted the Earth through increased pollution, greenhouse gases, deforestation, and sprawling development. The consequences of anthropopressure on the environment have led to intensified climate change, soil erosion, poor water and air quality (National Geographic, n.d.); the damages are usually permanent and have negatively affected large areas of the earth (Chmielewski, Kusztal, \& Zeber-Dzikowska, 2018). Venter (2016) and his team confirmed that three-quarters of Earth's land surface is subjected to anthropopressure. In the global footprint map that they presented, the Philippines is marked with a red color. This means that the Philippine environment has been facing the highest pressure from humans. Their report was attested by the most controversial and abrupt closure of Boracay island last April 26, 2018. Boracay Island is a prime tourist attraction in The Philippines, yet it was tagged as a cesspool. It was found that some of its drainages had a coliform count more than a hundred times higher than the recommended safety limit. Moreover, major problems that emerged on the island include improper garbage disposal and illegal wastewater dumping - both are anthropogenic (Department of Environment and Natural Resources, 2018). USAID (2019) also believed that the Philippines' rich biodiversity has been under threat, mostly from human activities. Hence, if most environmental problems in the Philippines are anthropogenic in nature, then human intervention is one of the best solutions (Li et al., 2014).

The Science, Technology, Engineering, and Mathematics (STEM) students being honed under the STEM disciplines, which are expected to provide an

Copyright (C) 2021 by Author/s and Licensed by Veritas Publications Ltd., UK. This is an open access article distributed under the Creative Commons Attribution License which permits unrestricted use, distribution, and reproduction in any medium, provided the original work is properly cited. 
array of skills and perspectives toward economic, social, and environmental sustainability among others (Smith \& Watson, 2018), may bring bold initiatives toward environmental protection and conservation in the future. Thus, it would be helpful to gauge in advance not only the status of their environmental literacy but also to find out whether they believe that their actions can create environmental impacts (environmental locus of control), and if they are inclined to consider future consequences of their actions/decisions (future orientation).

\section{Environmental Locus of Control}

Locus of control (LOC) is a personality variable that refers to the extent to which people believe they have power over events in their lives. It measures generalized expectancies for internal versus external control of reinforcement. A person with an internal locus of control attributes success to his or her efforts and abilities; he/she believes that he/she can influence events and their outcomes. On the contrary, someone with an external locus of control blames outside forces for everything and that their behavior does not matter much; the rewards in life are generally outside of their control (Rotter, 1966).

Many kinds of research on the LOC as a consequence construct have emerged in different disciplines such as in marketing (Cleveland et al., 2012; Ferguson \& Higgins, 2015), education (Atewe \& Aloka, 2018; Haudry, 1988, 1989; Wang, 2005), psychology (Hannafin, 1984; Haudry, 1989; Griffin, 2014), and so on. In the science context, the construction of instruments to assess specific attitudes such as LOC orientation in situations requiring familiarity in scientific principles and processes had remained challenging due to the question of the validity of the items. Thus, this elicited attention from many researchers (Cannon \& Scharmann, 1996; Haudry, 1988, 1989; KennedyMoore \& Watson, 1999) which then paved the way for the conception of the Science Locus of Control (SciLOC) Scale, a science contextualized LOC questionnaire.

The strong link between LOC orientation and attitude toward science teaching has long been recognized to the extent that a study was even done to establish the fact that SciLOC orientation of students can be modified and intervened or improved through instruction (Haudry, 1989). In the Philippine context, Lopez (1997) had done a study on the influence of LOC and SciLOC on the attitude of freshmen students toward Science and science achievement. His reports showed that SciLOC appeared to be a special case of the general locus of control and that it was a significant predictor of science attitude and achievement. The general establishment of LOC in determining students' science attitudes and outcomes (Atibuni et al., 2017; Brooks \& Hounshell, 1975; Haudry, 1988) helped facilitate the testing of LOC's association with the environmental contexts, one of the fields of science. Accordingly, succeeding researchers have found that LOC is related to the adoption of green behavior/ environmental intentions/ behaviors/ decisions (Balderjahn, 1988; Cleveland et al., 2005; McCarty \& Shrum, 2001). Notably, it was found that persons with a high internal locus of control are more inclined to develop a protective environmental behavior (McCarty \& Shrum, 2001) and that one's belief regarding his/her ability to control the state of the environment is the most important psychological regulating pro-environmental factor (Cleveland et al., 2012).

Many studies had used various scales to assess LOC linking to Pro-environmental Behavior (e.g., Smith-Sebasto \& Fortner, 2010; Sanford, 1985). However, contemporary researchers (Cleveland et al., 2005; Smith-Sebasto \& Fortner, 2010) urged that the scales used were either conceptually and/or methodologically flawed. In 2005, Cleveland et al. developed the Environmental Locus of Control (ELOC) scale; likewise, they suggested that this scale would still need further development and refinement to uncover potential antecedents. So, this led to the development of the internal environmental locus of control (INELOC) Scale in 2012 by Cleveland et al. (2012). The recent work of Cleveland et al. (2012) did not explain the meaning of the four dimensions of INELOC, namely, green consumer, activism, advocate, and recycling attitudes. But, for this study, the dimensions are briefly defined. The meanings are coined based on the sample questions for every INELOC dimension (Cleveland et al., 2012, p. 298).

1. Green consumerism refers to the belief of an individual that by patronizing or purchasing environment-friendly products, they can help the environment and encourage companies to be environment "friendlier".

2. Activism refers to the belief that individuals can work or do something to combat environmental issues by volunteering and supporting environmental organizations.

3. Advocate is the belief that an individual can influence or convince their friends or comrades to live and develop a proenvironment lifestyle.

4. Recycling attitudes are the belief of an individual that through recycling, he or she can improve or mitigate the worsening condition of the environment and natural resources. 
As of this writing, the INELOC Scale is the latest developed scale, excerpting all possible antecedents in measuring the environmental locus of control of a respondent. Thus, the INELOC Scale was adopted in this study.

\section{Future Orientation}

Future orientation (FO) refers to the scope to which a person takes into account the immediate or distant consequences and influences of his/her behavior (Strathman et al., 1994). Certain behavioral signs and traits could be exhibited by individuals depending on their time perspectives, and these time perspectives when combined with various circumstances may contribute to their own failure or success (Zimbardo \& Boyd, 1999). Determining the time perspective of individuals at different life stages is important since time perspective could affect decisions, especially of social goals, and can influence emotions, cognitions, and motivation of anyone (Laureiro-Martinez et al., 2017). Also, FO is recognized to help in fulfilling long-term goals as it can bring positive consequences to individuals (Carmi, 2012).

Studies about FO became more prominent particularly when United Nations Educational Scientific and Cultural Organization (UNESCO) made a declaration titled, Responsibilities of the Present Generations towards Future Generations, which focused on biodiversity and the protection of the environment among others (UNESCO, 1997). To abide by the declaration, many environmental initiatives nowadays prioritize FO to promote sustainability.

FO is a vital component of environmental education. Results from extant research revealed that FO is correlated to community's inclination to using public transport system (Joireman et al., 2003), water conservation (Corral-Verdugo et al., 2006), waste reduction (Ebreo \& Vining, 2001), and proenvironmental behavior (Carmi \& Arnon, 2014; Joireman et al., 2001). Furthermore, most of our environmental problems are the adverse effects of unsustainable activities done in the past (European Environment Agency, 2016; Marten, 2001). One must have to develop an urge in protecting the environment and accountability for the environment's condition for future generations to enjoy (Joireman, 2005). Therefore, it would be an advantage for a society to have a future-oriented citizenry who is more inclined to consider the effects of their behaviors toward the environment. It is for this reason that FO has been the subject of many studies by environmental researchers, including this one.

\section{Environmental Literacy}

The United Nations is of paramount importance in the beginnings of environmental literacy (EL), particularly when UN Member States were compelled to conduct research on the components of environmental literacy (UNESCO, 1978). Also, the North American Association for Environmental Education, an esteemed association advocating accelerated EL and civic engagement through education materials, had contributed greatly during the early conceptualization of the standards for environmental education. They identified seven elements of EL and used them as a framework in the development of EL in the United States. These elements include "affect; ecological knowledge; socio-political knowledge; knowledge of environmental issues; skills on environmental problems/issues and action strategies, systemic thinking, and forecasting; determinants of environmentally responsible; and behavior" (Hollweg et al., 2011, p. 2-3). A review by Hollweg et al. (2011) about the Developing Framework for Assessing Environmental Literacy done by the NAAEE in 2011, describes an environmentally literate as:

Both individually and together with others make informed decisions concerning the environment; is willing to act on these decisions to improve the well-being of other individuals, societies, and the global environment; and participate in civic life. (p. 2-3)

Furthermore, Hollweg et al. (2011) elaborate that:

Those who are environmentally literate possess to varying degrees: the knowledge and understanding of a wide range of environmental concepts, problems, and issues; a set of cognitive and affective dispositions; a set of cognitive skills and abilities; and the appropriate behavioral strategies to apply such knowledge and understanding in order to make sound and effective decisions in a range of environmental contexts. (p. 2-4)

The first wave of national assessments in environmental education conducted in the US during the 1970s focused on environmental knowledge and attitudes alone, while the second wave of national assessments began to test a wider range of EL components, focusing beyond environmental knowledge and attitudes (Hollweg et al., 2011). Then, the first international assessment that included multiple components of environmental literacy was administered in 2006 as part of the Programme for 
International Student Assessment (PISA) Science Assessment (OECD, 2012). Yet, despite all the EL components being assessed, some researchers (Hollweg et al., 2011; Marcinkowski, 2010) agree that it is impossible to assess all EL components and features in any single assessment. They argue that those EL components that can be assessed are usually too much to be assessed or some are just immeasurable to assess in any depth within a single large-scale international or national assessment. Thus, the developers of every international and national assessment of EL need to select and prioritize which components to include early in the process of developing an assessment framework.

Over the years, while many countries have been improving on their environmental performances (Environmental Performance Index, 2020), regrettably, environmental problems have aggravated (Stockholm Resilience Centre, n.d.). Thereby, education stakeholders would agree on the necessity of acquiring data to measure the status of EL across subjects (Williams, 2017; Wu et al., 2020). In the Philippines, the academe as mandated by Republic Act (RA) 9512, is continuously encouraged to promote environmental education and to continuously assess the Philippine condition (Congress of the Philippines, 2008). Consequently, the Department of Education integrated EL at all grade levels through a spiral progression curriculum. Grade 10 completers are assumed to have already developed "scientific, technological and environmental literacy so that they will not be isolated from the society where they live, will not be overwhelmed by change, and can make rational choices on issues confronting them" (DepEd, 2012, p.4). This was the premise that drove Nunez and Clores (2017) to assess the EL of Grade 10 students from both private and public schools which revealed a moderate level of environmental knowledge and behavior, and a high level of environmental attitude. To date, there have been quite a few studies measuring EL of several subjects in the Philippines. An earlier study conducted by Oliva (2013) obtained a low EL level among college students in private and public schools. Another study evaluated the capacity of teachers in implementing Philippine RA 9512 after a decade of conception from 2008 to 2018 by assessing their EL (Garcia \& Cobar-Garcia, 2016). The result was an eye-opener as it revealed the limited readiness and capacity of the teachers to implement environmental education in compliance with RA 9512 due to the lack of environmental knowledge and science-based competencies. Interestingly, there was a lone study taken on communal and societal context (Contreras et al., 2015) which was rooted in the idea of the Philippines being a disaster-prone country - brought by anthropogenic activities and heightened by its geographic location. In this study, the researchers assessed a typhoon-prone island residents' EL, environmental awareness, and disaster preparedness. They found out that the community was not very much knowledgeable about environmental issues. The authors further claimed that residents there were also not yet fully aware of what they needed to do in case an unpredictable natural phenomenon would occur.

The subjects for EL research in the Philippines as presented in this section are diverse. However, all the EL results were fair if not unsatisfactory. Suffice to say that drawing more studies to EL based on the Philippine context may validate previous researches and may reveal inexplicable areas where educational advances and researches appear to be needed. In the end, improving EL is equivalent to preparing people to understand and address persistent environmental issues, and as Hollweg et al. (2011) claimed, an environmentally literate public is of great advantage in the discovery of workable and evidence-based solutions for many environmental issues.

\section{Gender}

Available literature shows that there have been few researchers who have embarked on the effects/relationships of gender on environmentalrelated components (e.g., Coyle, 2005; Hayes, 2001), locus of control (e.g., Flores et al., 2020; Sherman et al., 2007), and future orientation (e.g., Greene \& DeBacker, 2004; Honora, 2002; Mello \& Worrel, 2006). Their results suggest that gender can either have significant effects (Coyle, 2005; Flores et al., 2020; Greene \& DeBacker, 2004; Honora, 2002; Sherman et al., 2007) or have no or little effect (Hayes, 2001, Mello \& Worrel, 2006) to the previously mentioned areas.

The growing research interests on the achievement gaps between male and female students have been observed due to their policy and economic implications (Meinck \& Brese, 2019; OECD, 2020), and its possible influence on attitudes, beliefs, opinions, and behavior (Eisler et al., 2003; Xiao \& McCright, 2013). In STEM-related field, gender disparity is apparent due to the greater number of male populations in the workforce (Cimpian et al., 2020; Hazari et al., 2007; World Economic Forum, 2017), except in Biology when the trend recently showed that there is no differential "pipeline leak" for women (Eddy et al., 2017; Luckenbill-Edds, 2002). This gender difference is perceived as gender inequality and purportedly can influence the societies' ability to shape environmental outcomes, thus, affecting environmental quality. 
In the 2015 United Nations General Assembly, education and gender equality have been recognized as integral parts of the 2030 Agenda for Sustainable Development (United Nations, 2015). Correspondingly, UNESCO (2017) recognizes girls and women as key players in our society. It promotes women for their contributions in crafting solutions to the common challenges which societies are facing today. This paper, therefore, aims to contribute to extant research on the effect of gender in environmental literacy, locus of control, and future orientation. The results of this study may also contribute to the importance of gender patterns that have evolved through the years.

\section{Science, Technology, Engineering, and Mathematics (STEM) Students}

STEM students are usually drilled and honed with all the advanced lessons, particularly in the STEM disciplines. In the Philippines, they are expected to add to the scientific and scholarly workforce of the country upon graduation (National Economic and Development Authority, 2017). They are exposed to a curriculum designed to develop learners' skills from simple to complex problems of the country and the world (Estonanto, 2017). Since most environmental problems in the Philippines are anthropogenic, it is assumed that STEM students, based on their background and training, can contribute toward environmental protection and conservation in the future. Thus, it would be helpful to gauge in advance not only the status of their environmental literacy but also to find out whether they believe that their actions can create environmental impacts, and if they are inclined to consider future consequences of their actions/decisions.

\section{Aims}

This study investigated the status of Philippine STEM students' environmental literacy (EL), environmental locus of control (ELOC), and future orientation (FO). Also, it explored both the relationships between the components of EL (Environmental Knowledge, Environmental Attitudes and Behavior, and Environmental Skills) and the dimensions of ELOC, and between the EL components and future orientation (FO). Lastly, it probed into the effect of gender among the dimensions and components of EL, ELOC, and FO.

\section{MATERIALS AND METHODS}

The SPSS Version 19.0 was used in this study. For basic information, the data sets were analyzed using descriptive statistics such as the frequency of scores, mean, and standard deviation. The Independent samples t-test was used to find out the significant effects of gender on the components of EL and the dimensions of ELOC and FO, and since the relationships among the said variables have to be established first, Pearson product-moment correlation coefficient $(r)$ was used to investigate on the possible relationships among the said variables. There was no interview done to verify and validate the answers of the respondents, which was one of the limitations of this study.

\section{Participants}

A convenient sample of 512 public school students participated in the study. The participants were grades 11 and 12 students enrolled in the Science, Technology, Engineering, and Mathematics (STEM) strand under the academic track of the Senior High School. There were 265 (51.76\%) male participants which were apparently higher compared to their female counterparts of 247 (48.24\%).

\section{Instruments}

The Internal Environmental Locus of Control (INELOC) Tool was used in excerpting all antecedents in measuring the environmental locus of control of the respondents. This was adopted from Cleveland et al. (2012). The INELOC Scale is a 7-point Likert-type scale $(1=$ strongly disagree and $7=$ strongly agree) which is composed of 16 statements. Seven items were modified to fit into the Philippine context. It has four dimensions, namely, Green Consumer, Activism, Advocate, and Recycling Attitudes.

The Consideration of Future Consequences (CFC) Scale was adopted from Strathman et al. (1994). It is composed of 12 items and uses a 4-point Likert-type scale $(1=$ extremely uncharacteristic to $4=$ extremely characteristic). The Scale was twodimensional which measured the extent to which students considered and were influenced by the immediate or distant outcomes of their current behavior. CFC Scale was scored such that higher numbers indicated a greater consideration to future or immediate consequences. No items of the CFC Scale was modified in this study. In the Philippines, CFC was used to correlate environmental decisionmaking and environmental values (Calsado, 2013).

The Environmental Literacy Test (ELT) was developed by Oliva (2013) and used to assess the EL of STEM students. The test was aligned with the environmental curriculum prepared by the Asian Development Bank for DENR-EMB and the Department of Education. In this study, STEM students' environmental literacy was measured through the three components of ELT: Environmental Knowledge (EK), Environmental Attitudes and Behavior (EA\&B), and Environmental Skills (ES). The 
Table 1. Categories of answers for environmental attitudes and behavior

\begin{tabular}{ll}
\hline Frequency & Description \\
\hline ALWAYS & every time; every day \\
FREQUENTLY & not always but more than sometimes \\
OCCASIONALLY & sometimes \\
RARELY & only when remembered/reminded \\
NEVER & does not care \\
\hline
\end{tabular}

EK and ES parts were both composed of 30-item and 10 -item objective questions, respectively. EK covered essential environmental topics such as aspects of the lithosphere, hydrosphere, atmosphere, biosphere, energy, and sustainability concepts. ES part, on the other hand, was composed of questions with scenarios and graphs that aimed to: assess the students' ability to analyze environmental problems; their ability to create a way to reduce environmental impacts; and their ability to contribute to broader societal efforts in protecting the environment. Lastly, the EA\&B part was a 20-item Likert-type scale that determined the attitude, habits, and behavior of students toward the environment. Table 1 shows the categories from which the students may choose their answers.

One item under the EA\&B part was modified to fit into the high school students' context, while 8 items under the ES part which included news clippings and graphs, were updated to fit the current Philippine context.

\section{Data Collection Procedure}

The instruments were pilot tested to 120 STEM students in public schools. The students answered the questionnaires in two sessions and in a self-paced manner. After the pilot-testing, the instruments were subjected to reliability analyses which yielded Cronbach's alpha values of .87 for INELOC Scale, .71 for CFC Scale, and .70, .74, and .66 for the ELT's components, namely, Environmental Knowledge (EK), Environmental Attitudes and Behavior (EA\&B), and Environmental Skills (ES), respectively. Environmental Skills' Cronbach's alpha of .66 was still regarded as acceptable by researchers (Taber, 2017).

Since the instruments used in the study were already validated and were adopted, there is no need to perform a validity analysis (Korb, 2012). However, since there were questions that were modified and updated to fit the Philippine setting and its current situation, the construct and content validity were still performed by three experts just to ensure that the modified questions were parallel and would still reflect the original questions. There were no major changes made in the instruments after the pilottesting except for the alignment and spacing in between the graphs and tables which were modified before the administration of the instruments on the actual respondents.

\section{RESULTS}

\section{Status of Environmental Literacy}

The STEM student's environmental literacy (EL) was measured using the three components of the Environmental Literacy Test (ELT), namely, Environmental Knowledge (EK), Environmental Attitudes and Behavior (EA\&B), and Environmental Skills (ES). The status of students' EK and ES is presented in Table 2. It revealed an EK rate of 53.45\% ( $M=16.04, S D=4.54$ ) which was below the passing grade of $60.00 \%$ in the Philippines (DepEd, 2015), while students' ES showed a high rate of $70.65 \%$ ( $M$ $=7.06, S D=2.07$ ).

Table 2 also reveals that gender has a significant effect on EK. It shows that female students have a higher level of EK $(M=16.10, S D=3.91)$ compared to male students $(M=15.97, S D=4.58)$, and the difference observed is significant, $t(510)=-0.348, p$ $=0.004$. For the students' ES, the results imply that female students exhibit high environmental skills ( $M$ $=7.14, S D=2.07)$ than male students $(M=6.99, S D$ $=2.07)$; however, the difference observed is not significant, $t(510)=-0.814, p=0.528$.

The summary of the students' EA\&B responses is presented in Table 3. The results showed that many of the students believed that they had never done or

Table 2. Means, standard deviations, and significant effects of gender on environmental knowledge and environmental skills of stem students

\begin{tabular}{cllllcccc}
\hline & \multicolumn{6}{l}{ Environmental Knowledge $($ EK $)$} & \multicolumn{5}{c}{ Environmental Skills $($ ES $)$} \\
\cline { 2 - 8 } Gender & Mean & Percentage & $S D$ & $t$-value & Mean & Percentage & $S D$ & -0.814 \\
Female & 16.10 & 53.67 & 3.91 & $-0.348^{*}$ & 7.14 & 71.40 & 2.07 & 2.07 \\
Male & 15.97 & 53.23 & 4.58 & & 6.99 & 69.99 & 7.06 & \\
Average & 16.04 & 53.45 & 4.54 & & 7.06 & 70.65 & 2.07 & \\
\hline
\end{tabular}

* correlation is significant at the 0.05 level (2-tailed)

Note. The maximum score for EK is 30; The maximum score for ES is $10 ; \mathrm{N}=512$

$S D=$ Standard Deviation 
Table 3. Most frequent response in environmental attitudes and behavior

\begin{tabular}{|c|c|c|c|}
\hline $\begin{array}{l}\text { Most } \\
\text { Frequent } \\
\text { Response }\end{array}$ & Description & Environmental Attitudes and Behavior & $\begin{array}{l}\text { Frequency } \\
\text { (out of } 512 \\
\text { responses) }\end{array}$ \\
\hline \multirow{12}{*}{ Never } & \multirow{12}{*}{ Does not care } & $\begin{array}{l}\text { 3. I turn off all electrical appliances and switches before I leave a room unused } \\
\text { by other occupants. }\end{array}$ & 363 \\
\hline & & $\begin{array}{l}\text { 4. I engrave my initials or name on reefs, trees, and other life forms I } \\
\text { encounter on any nature trips }\end{array}$ & 332 \\
\hline & & $\begin{array}{l}\text { 5. I throw used motor oil, cooking oil, and other used oils in the house into } \\
\text { drainage canals. }\end{array}$ & 229 \\
\hline & & 9. I tighten faucets in public toilets when I see water dripping. & 274 \\
\hline & & 10. I reuse paper for drafts and other informal writings. & 234 \\
\hline & & 11. I spit on public streets. & 255 \\
\hline & & 13. I dispose of used electronics with garbage and other household wastes. & 158 \\
\hline & & 14. I flush tissue down the toilet. & 380 \\
\hline & & 16. I leave the refrigerator door open for a long time. & 399 \\
\hline & & 17. I walk instead when going to nearby areas. & 308 \\
\hline & & 18. I reuse plastic bags and containers. & 257 \\
\hline & & 19. I throw away candy wrappers or any small trash on public roads or parks. & 226 \\
\hline \multirow{3}{*}{ Rarely } & \multirow{3}{*}{$\begin{array}{l}\text { Only when } \\
\text { remembered / } \\
\text { reminded }\end{array}$} & 1. I segregate biodegradable from non-biodegradable wastes. & 221 \\
\hline & & 6. I patronize energy-efficient and environment-friendly products. & 188 \\
\hline & & $\begin{array}{l}\text { 7. I share with other people information on how to act responsibly toward the } \\
\text { environment. }\end{array}$ & 208 \\
\hline \multirow{3}{*}{ Occasionally } & \multirow{3}{*}{ Sometimes } & 12. I will let the water run while soaping my hand. & 146 \\
\hline & & 15. I buy refills and concentrates as they involve less packaging. & 183 \\
\hline & & 20. I buy organic products. & 221 \\
\hline Frequently & $\begin{array}{l}\text { Not always but } \\
\text { more than } \\
\text { sometimes }\end{array}$ & 8. I plant trees whenever there is an opportunity. & 154 \\
\hline Always & $\begin{array}{l}\text { Every time; } \\
\text { Every day }\end{array}$ & 2. I kill or trap animals only if there is a real need and there is no alternative. & 158 \\
\hline
\end{tabular}

never had attitudes or behavior against the environment, specifically on the following situations: I engrave my initials or name on reefs, trees, and other life forms I encounter in any nature trips; I throw used motor oil, cooking oil and other used oils in the house into drainage canals; I spit on public streets. I dispose of used electronics with garbage and other household wastes. I flush tissue down the toilet. I leave the refrigerator door open for a long time; I throw away candy wrappers or any small trash on public roads or parks. However, while most students signified that they did not harm the environment, many of them also had shown indifference to their environment by not caring at all, specifically in the following statements lifted from the items in the questionnaire: I turn off electrical appliances and switches before leaving a room unused by other occupants; I tighten dripping public faucets; I reuse paper for drafts and other informal writing; I walk instead when going to nearby areas; I reuse plastic bags and containers.

\section{Status of STEM Students' Environmental Locus of Control (ELOC)}

The students' ELOC was measured using the INELOC Scale. Among its four dimensions, the Recycling Attitudes got the highest mean $(M=6.20)$, while the Advocate ( $M=5.50)$ got the lowest, as shown in Figure 1.

\section{Status of STEM Students' Future Orientation}

The Consideration of Future Consequences (CFC) Scale was used to measure the future orientation of the students. The result shown in Figure 2 indicates that students have greater consideration for the future consequences of their action than meeting their immediate needs or concerns. 


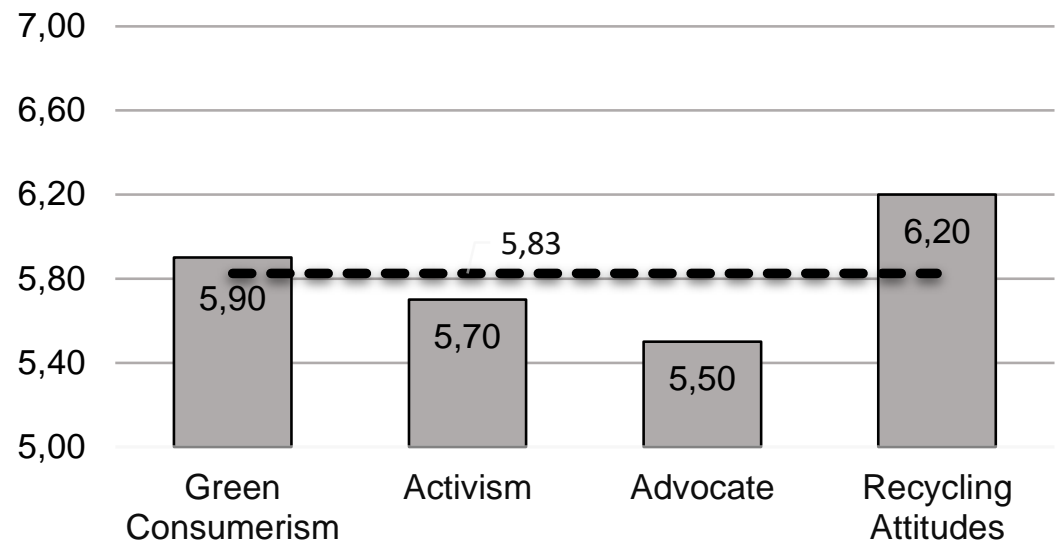

Note. The highest possible answer is 7.

Figure 1. Dimensions of internal environmental locus of control

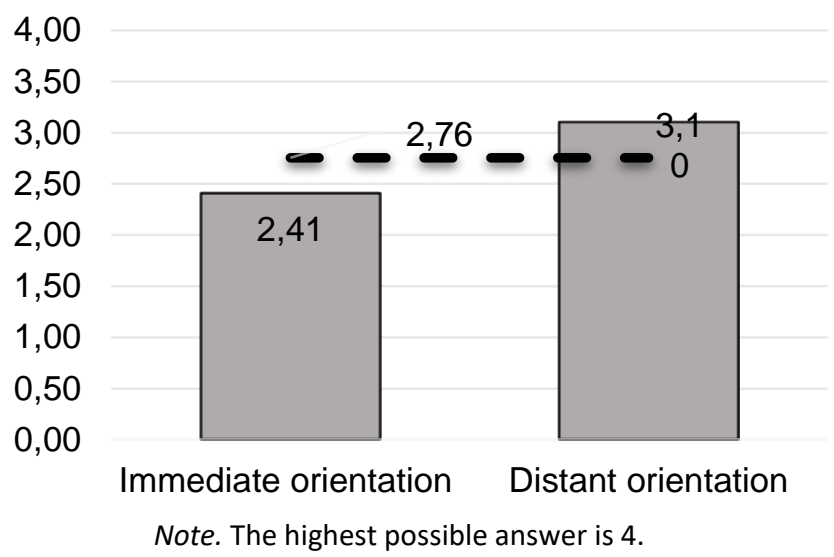

Figure 2. Summary of consideration of future consequences (CFC) scale

Effect of Gender on the INELOC Dimensions and Future Orientations of STEM Students

Females have significantly higher mean scores (Table 4) in the advocate and recycling attitudes dimensions, $t(510)=-1.812, p=0.012$, and $t(510)$ $=-2.837, p=0.002)$, respectively, than their male counterpart which has significantly lower mean scores for advocate $(M=5.47, S D=0.93)$ and recycling attitudes $(M=6.13, S D=0.85)$ dimensions.

Moreover, Table 5 shows that gender has neither significant effect to immediate nor distant orientation of the students even if female students exhibit higher distant orientation $(M=3.10, S D=0.38)$ than male students $(M=3.09, S D=0.40)$, at $p=0.224$, nor male being more immediate-oriented $(M=2.45, S D=$ $0.51)$ compared to female students $(M=2.37, S D=$ $0.46)$, at $p=0.073$.

Relationships among the Environmental Literacy (EL), Environmental Locus of Control (ELOC), and Future Orientation (FO)

Table 6 presents the results of exploring the relationships of EL and ELOC and EL and FO through their components and/or dimensions. It was revealed that among the components of EL, the students' EK and ES were significant, weak, negative, correlated only to AD dimension, $r(510)=-0.096$ and -0.136 , respectively, at $p<.05$. , and to immediate orientation, $r(510)=-0.257$ and -0.289 , respectively, at $p<.01$. Interestingly, only the EA\&B yielded weak, negative correlations with all ELOC dimensions, namely, GC, AC, AD, and RA, $r(510)=-$ $0.214,-0.233,-0.288$, and -0.251 , respectively, and to immediate orientation, $r(510)=-0.243$. EA\&B relationships are all significant at $p<.05$.

\section{DISCUSSION}

\section{Status of Environmental Literacy}

The STEM students' very low Environmental Knowledge (EK) mean score suggested that the students either failed to retain environmental concepts taught to them, or the students did not have a good grasp of these environmental concepts. This result has confirmed Oliva's (2013) and Nunez's and Clores' (2017) reports on the relatively low level of EL among students in the Philippines. Consequently, 
Table 4. Means, standard deviations, and significant effect of gender on INELOC dimensions

\begin{tabular}{llllll}
\hline $\begin{array}{l}\text { INELOC } \\
\text { Dimensions }\end{array}$ & Gender & $N$ & Mean & $S D$ & t-value \\
\hline Green & Male & 265 & 5.85 & 0.88 & -2.734 \\
Consumerism & Female & 247 & 6.05 & 0.78 & \\
Activism & Male & 265 & 5.66 & 0.86 & -2.219 \\
& Female & 247 & 5.82 & 0.77 & $-1.812^{*}$ \\
Advocate & Male & 265 & 5.47 & 0.93 & $-2.837^{*}$ \\
& Female & 247 & 5.61 & 0.79 & \\
Recycling & Male & 265 & 6.13 & 0.85 & 0.66 \\
Attitudes & Female & 247 & 6.32 & & \\
\hline
\end{tabular}

* correlation is significant at the 0.05 level (2-tailed)

Table 5. Means, Standard deviations, and significant effect of gender on CFC components

\begin{tabular}{clllll}
\hline $\begin{array}{c}\text { CFC } \\
\text { Components }\end{array}$ & Gender & $N$ & Mean & $S D$ & t-value \\
\hline Immediate & Male & 265 & 2.45 & 0.51 & 1.830 \\
orientation & Female & 247 & 2.37 & 0.46 & -0.105 \\
Distant & Male & 265 & 3.09 & 0.40 & 0.38 \\
$\quad$ orientation & Female & 247 & 3.10 & & \\
\hline
\end{tabular}

Note. Correlation is significant at the 0.05 level (2-tailed)

the result of this study implicitly tells that K-12 Basic Education Curriculum in the Science area has a propensity to fail in achieving its goal of developing environmentally literate students and responsible stewards of nature if EK is not addressed, as environmental knowledge is an antecedent to proenvironmental behavior (Chapman \& Sharma, 2002; Latif et al., 2013). Hence, this should compel wellthought instructional intervention processes to improve STEM students' understanding of environmental topics. Furthermore, education sectors have to reflect and assess the effectiveness of their approach and pedagogy in teaching environmental concepts. Teachers might need to go beyond environmental theories and engage students in authentic experiences - providing them with active roles in the process of learning environmental topics.

It is also notable that the Environmental Skills (ES) of students was so much higher than EK. The type of questions in the ES part could have affected how the students answered them. The ES part was composed of questions that required the students to apply their skills in interpreting graphs/charts/articles for them to analyze environmental problems, suggest a way to reduce environmental impacts, and contribute to broader societal efforts in protecting the environment. Chances were, if the students understood what the graphs/charts/articles would want to convey, they would be able to get the questions right. The skills of the STEM students being constantly honed through their sciences, technological, engineering, and mathematical courses might have helped them to achieve high percentage scores in this particular part (Official Gazette, n.d.). Thus, with high ES, it would be good to continuously engage the students in relatable and authentic class/school activities such as those which require them to utilize their ES in proposing solutions to commonly encountered environmental problems.

The students' Environmental Attitudes and Behavior (EA\&B) result implied that many of the students believed that they had never done or never had attitude or behavior against the environment (e.g. disposing of used electronics with garbage and other household wastes, throwing away candy wrappers or any small trash on public roads or parks.). But, many of them also had shown indifference to their environment by not caring at all (e.g. turning off electrical appliances and switches before leaving a room unused by other occupants, tightening dripping public faucets.). The indifference exhibited by the students in their EA\&B might have been due to certain factors that cannot be verified or elicited due to the limitation of the questionnaire used. Nonetheless, in this study, relevant literature was exhausted to possibly explain this behavior.

Many of the students would not care anymore to close dripping public faucets in public toilets because 
Table 6. Correlations among the components of environmental literacy dimensions of environmental locus of control, and future orientation

\begin{tabular}{|c|c|c|c|c|c|c|c|c|c|}
\hline Variables & 1 & 2 & 3 & 4 & 5 & 6 & 7 & 8 & 9 \\
\hline \multicolumn{10}{|l|}{$\begin{array}{l}\text { Environmental } \\
\text { Literacy }\end{array}$} \\
\hline $\begin{array}{l}\text { 1. Environmental } \\
\text { Knowledge (EK) }\end{array}$ & - & & & & & & & & \\
\hline $\begin{array}{l}\text { 2. Environmental } \\
\text { Attitudes and } \\
\text { Behavior (EA\&B) }\end{array}$ & $-0.267^{* *}$ & - & & & & & & & \\
\hline $\begin{array}{l}\text { 3. Environmental } \\
\text { Skills (ES) }\end{array}$ & $0.554^{* *}$ & $-0.302^{* *}$ & - & & & & & & \\
\hline \multicolumn{10}{|l|}{$\begin{array}{l}\text { Environmental Locus } \\
\text { of Control }\end{array}$} \\
\hline $\begin{array}{l}\text { 4. Green } \\
\text { Consumerism } \\
\text { (GC) }\end{array}$ & 0.040 & $-0.214^{* *}$ & 0.045 & - & & & & & \\
\hline 5. Activism (AC) & 0.068 & $-0.233^{* *}$ & 0.050 & $0.575^{* *}$ & - & & & & \\
\hline 6. Advocate (AD) & $-0.096^{*}$ & $-0.288^{* *}$ & $-0.136^{*}$ & $0.400^{* *}$ & $0.471^{* *}$ & - & & & \\
\hline $\begin{array}{l}\text { 7. Recycling } \\
\text { Attitudes (RA) }\end{array}$ & -0.027 & $-0.251^{* *}$ & -0.026 & $0.546^{* *}$ & $0.507^{* *}$ & $0.458^{* *}$ & - & & \\
\hline \multicolumn{10}{|l|}{ Future Orientation } \\
\hline $\begin{array}{l}\text { 8. Immediate } \\
\text { orientation }\end{array}$ & $-0.257^{* *}$ & $0.300^{*}$ & $-0.289^{* *}$ & -0.056 & $-0.105^{*}$ & $-0.094^{*}$ & -0.116 & - & \\
\hline $\begin{array}{l}\text { 9. Distant } \\
\text { orientation }\end{array}$ & 0.085 & $-0.243^{*}$ & $0.092^{*}$ & $-0.269 * *$ & $0.248^{*}$ & $0.255^{* *}$ & $0.191^{* *}$ & $-0.200^{* *}$ & - \\
\hline
\end{tabular}

Note: ${ }^{*}$ correlation is significant at the 0.05 level (2-tailed)

** correlation is significant at the 0.01 level (2-tailed)

they might have assumed that these are not functional (Katsuno et al., 2019). Also, students might not prefer to walk even if they just go to nearby areas because of the extreme dry-wet climate of the Philippines. At times when the rain pours, it can flood streets; and when it is sunny, the scorching heat of the sun can be unbearable as well. Moreover, the schools where the respondents were enrolled usually had two class shifts: morning and afternoon shifts, to accommodate the number of students. Those students in the morning shift must go to school early in the morning and go home at midday, and those who are in the afternoon shift must go to school at midday and go home in the evening. These were the situations that the students had to deal with every day and walking alone might not be convenient and safe since they had to leave or reach their homes at dawn or dusk. Moreover, the ubiquitous presence of cheap mobility options such as buses, jeepneys, and other three-wheelers transport such as tricycles/pedicab (Boquet, 2017) might have compelled the students to take the mobile transport system as it is more convenient than walking. To sum up, though the result dictates that the students tended to not walk even when going to nearby areas, further inference was limited since students' contexts were not taken into consideration.

Lastly, the students signifying that they had never reused plastic bags and containers confirmed the Philippines along with Vietnam as the world's thirdhighest share of mismanaged plastics (Ritchie, 2018). Though the statement in the instrument was general, just plastic bags, it could have been better if in the instrument, which the students answered, the item was more specific such that students could indicate their inclination to either reusable bags/containers or single-use disposable plastics/containers. Nonetheless, it would be helpful if students' EK on the advantages of managed and mismanaged used plastics would be improved first, for a deep understanding of the environmental concepts and knowledge precedes pro-environmental actions (Chapman \& Sharma, 2002; Latif et al., 2013). Without a good foundation of EK, (evidently seen on the relatively low EK result), students might not be able to behave positively toward the environment. Thus, there should be enough opportunities given to students to develop their pro-EA\&B and to deepen their EK because even if students are willing to have pro-environment behavior but not given enough practice, doing it will not become natural or habitual 
(Kollmuss \& Agyeman, 2002). Regrettably, looking through the $\mathrm{K}$ to 12 Science Curriculum (DepEd, 2016), it is noted that environmental education topics are not consistently integrated into all fields of science. Most of the time, integrating environmental education in the curriculum has become a prerogative of teachers to the extent that teachers integrate environmental education in their lessons only if the academic time permits it.

Status of STEM Students' Environmental Locus of Control (ELOC)

The high mean result of the Recycling Attitudes (RA) dimension suggested that many students believed that through recycling, they could create environmental impacts. This could be because, among the four INELOC dimensions, it is the recycling initiative that is most well-communicated in the Philippines: in the schools where the STEM students were from, one could see the big bins intended for the recyclable materials; school projects oftentimes recommend the use of recyclable materials to reduce the cost of production; in shopping malls, the use of recyclable bags and proper disposal of recyclable electronics/materials have been highly encouraged through the visible posters found everywhere; lastly, the stories of people who became successful and made money by buying and selling recyclable materials (e.g., Garcia, 2013) and melodramatic stories of poor recyclable-material-scavengers (e.g., GMA Network, 2016) have pervaded mass media recently.

Conversely, Advocate (AD) had the lowest mean among the four dimensions of INELOC. This meant that fewer students believed that they could influence or convince their friends or comrades to live and develop a pro-environment lifestyle. Students might have found convincing their friends to live a proenvironmental lifestyle challenging since their friends also had their preferences. It could also be that among the four dimensions, it was advocating for the environment that is found as the most demanding by the STEM students. Looking through the questionnaire, the items included under the $\mathrm{AD}$ dimension notably require acceptance or positive response from the person that the students are advocating pro-environmental activities with (e.g., I am able to convince a friend to improve his/her conservation habits; to some degree, I can influence my friends to choose walking or riding a bike when going to areas within short distances), and in comparison to items in other dimensions, the items in other dimensions do not require a positive response from a receiver of their environmental initiatives (e.g., by recycling, I am saving valuable natural resources; by giving money to environmental groups,
I can help increase their probability of success). In this context, education sectors may improve environmental advocating initiatives to the youth by promoting environmental campaigns. Practically, this can be done through the established existing school environmental groups where students are more familiar with (e.g., YES-O organization). Various campaigns can also be initiated to enlighten the students on the importance of advocating for the environment, its impacts, and the different and creative ways to advocate for the environment in addition to the items/options stated in the INELOC questionnaire. There should also be provisions for these environmental campaigns to be more inclusive, catering to students with different abilities or inclinations, and engaging to students for them to become more active and concerned with the current environmental condition. In addition, to maintain all the students' dimensions high, teachers may connect Green Consumerism (GC) and RA having the highest mean, to Activism (AC) and Advocate (AD). For example, in this social media age, teachers may encourage their students to join "known" and "safe" environmental groups or create their own environmental support groups on social media (AC). Through this social media platform, students who patronized environment-friendly products may post their patronized products on their social media group (AD and GC). Another option is for students to share on social media how recycling can be a way of living sustainably (AD \& RA). Ultimately, it is important to point out to students that advocating for the environment need not be vocal; it can be done by posting on social media or by a living example.

\section{Status of STEM Students' Future Orientation (FO)}

The higher mean score of STEM students on distant orientation than immediate orientation revealed that the majority of the students considered greatly the future consequences of their actions and that they were willing to sacrifice their present convenience to achieve a greater result in the future. Furthermore, the result also implied that the STEM students tend to use their goals as guides for their future actions (Strathman et al., 1994).

The environmental problems that society are experiencing now are the adverse effects of unsustainable activities that are done in the past. The communities' present day-to-day activities may not manifest the adverse effects on the environment instantly. It might require years before it would become apparent and usually too late to mitigate or too complex to solve its aftermath. Individuals who are distant or future-oriented are assumed to be inclined to foreseeing these possibilities or the consequences of their actions (Zimbardo \& Boyd, 
1999). It is a great advantage, therefore, to have a society of future-oriented thinkers because they most likely demonstrate more pro-environmental tendencies (Carmi \& Arnon, 2014). So, it is suggested that school programs and activities provided for the students may focus on the inculcation of delay of gratification, goal setting, cost-benefit analysis, and planning, among others (Zimbardo \& Boyd, 1999). Furthermore, it would be of great advantage to society if programs and activities prepared for students to cultivate their FO would utilize environmental platform or context, thus, strengthening students' environmental understanding at the same time. Additionally, since planning in consideration of the future is one of the essential procedures which future-oriented individual would usually do (Carmi, 2012; Prenda \& Lachman, 2001; Zimbardo \& Boyd, 1999), suffice to say that the STEM students in this study having found to consider distant outcomes of their actions, may also be inclined to planning (Connell, 2009; Johnson et al., 2014). In this connection, continuous honing of students' planning skills is necessary. Instructionalmaterial developers may design activities that would allow future-oriented students to propose doable plans in dealing with some environmental problems faced in their communities.

Significant Effects of Gender on INELOC Dimensions and Future Orientations of STEM Students

The insignificant effect of gender to immediate and distant orientation of students confirmed the study of Mello and Worrel (2006) having found gender to be not associated with any other time perspective dimension. Also, the higher EK mean scores of females than males for the advocate and recycling attitudes dimensions could probably be attributed to women being more environmentally motivated and less skeptical than men (OECD, 2020). As social norms dictate, females are expected to be more caring and more responsible for maintaining cleanliness at home and in their surroundings (Liang et al., 2018). These might have given them an inadvertent advantage of learning more about the environment, hence, making them more concerned and knowledgeable about environmental concepts than males. This result, females having significantly higher mean scores, is the same with a few extant research (Alp et al, 2008; McCright, 2010) yet inversely with others (Hayes, 2001; Vicente-Molina et al., 2018; Xiao \& Hong, 2016) including a recent local study done by Nunez and Clores (2017). This result disparity of having females scoring higher than males could be the outcome of complex interaction and effect of gender to STEM students' academic achievement (Honora, 2007), or it could also be the positive effect of concerted efforts of the Philippine society in empowering and closing the gender gap in educational attainment as reported in the Global Gender Gap Report 2017 (World Economic Forum, 2017). Nonetheless, it would be good if more local studies are drawn to this area of research to contribute to gender patterns results and/or to shed light on these gender differences.

Relationships among the Environmental Literacy (EL), Environmental Locus of Control (ELOC), and Future Orientation (FO)

All the EL components had a significant, weak, negative relationship only to the Advocate (AD) dimension of ELOC. This implied two things: first, as the student's EL (EK/EA\&B/ES) increased, his/her belief that he could influence or convince his/her friends or comrades to live and develop a proenvironmental lifestyle (AD) declined, or as a student believed that he could influence or convince his/her friends or comrades to live and develop a proenvironmental lifestyle (AD), his/her EL decreased; second, it is possible that another factor (or even a whole set of other factors) may give rise to the increase of EL yet to the decline of AD. It is likely that as a student becomes environmentally literate, he/she may realize that advocating for the environment becomes more difficult to carry out especially if he/she would do it "right"; this is not convenient - socially, emotionally, or culturally. As Diekmann \& Preisendörfer (2003) stated, environmental attitude and low-cost proenvironmental behavior (do not pertain to economic factors alone but also to psychological factors among others) do correlate significantly. People who care about the environment tend to engage in activities only if it is not costly and inconvenient for them.

Moreover, it was worth noticing that the insignificant results with almost no correlation were from relationships between EL and GC, and EL and $\mathrm{AC}$, where statements included in the INELOC Scale involved monetary decisions, e.g., The more I buy environment-friendly products, the more I help persuade the companies to become "friendlier" to the environment (for GC); Any donation to environmental groups such as Greenpeace help attain its goals (for $A C$ ). Students might have reacted to the statements that required monetary involvement differently as they may take into consideration their financial capabilities being (still) financially dependent on their source. In other words, while others might be willing to spend an extra amount for the environment, some might not bother to spend a single cent for the environment as they may have thought that the money which they are spending is not theirs. This idea is consistent with that of De 
Dominicis et al. (2017) pointing out that when money is made salient, individuals tend to behave more selfishly no matter what the goal of their actions is.

The inverse correlations of the EA\&B to ELOC dimensions and distant orientation are deviations from a few researches that focused on locus of control of their respondents (Giefer et al., 2019; Weimer et al., 2017). In this study, the STEM students' ELOC might have been affected by the widespread environmental campaigns which persistently call for humans' environmental accountability. Environmental campaigns on social or mainstream media have emphasized greatly how the behavior of a community can create an impact on the environment (locus of control). With this constant exposure of the students, they might have acquired an instant inclination to the dimensions of INELOC because it became common knowledge for them that individuals are capable of controlling environmental outcomes yet understanding their environmental accountability which requires environmental background is just superficial (as revealed by low environmental knowledge). Furthermore, this deviant result could also be the effect of the academic achievements of students. As Mohd Khir and Redzuan (2017) claimed, the respondents' academic achievements could bring a significant difference in their locus of control. In the Philippines, STEM students are considered the best students academically since they have taken admission tests and maintained good grades for them to qualify under the STEM track. As they academically progress, their inclinations to develop an internal locus of control might also have progressed. Suffice to say that the students in this research might have acquired an internal LOC through the years of academic upgrading under the STEM track. The STEM students' answers in EA\&B might have also been dictated by economic consideration and practicality. This is supported by Yumusak et al. (2016) who suggested that people tend to behave environment-friendly as long as in accordance with their interests and no additional cost is required. In one item that measured students' EA\&B for example, if buying environmentfriendly products is not practical for a student because of their additional cost, even if he/she is environmentally inclined, he/she may not practice buying them because he/she needs to be practical. The same is true when a student prefers not to walk when going to nearby areas because it prioritizes its own safety over the environment. Situations like these may have affected the results. To address these predicaments, all stakeholders particularly the education sector should work together to: deepen the understanding of the students of their environmental accountability; strengthen the idea among the students that they can have great impacts - make or break the environment; lastly, promote altruistic behavior toward the environment - expressing concern for others (e.g., next generation) and nature first before self. However, developing altruistic behavior, putting others first before self, would be very challenging as it contradicts the human nature of self-preservation.

The significant, weak, negative correlations between the EK and ES to the immediate orientation implied that a higher EK/ES score was weakly related to a lower measure of the students' immediate orientation which revealed that a student who was environmentally knowledgeable/skilled might not be inclined to meeting his/her immediate needs or to consider the immediate consequences of his/her actions. Taking the environment into consideration, it is possible that an environmentally knowledgeable/skilled student may not just focus on his/her immediate needs or consequences of his/her action but also take into account the future of the environment. A student who is more concerned about the future of the environment may be compelled to learn more about the environment, hence, improving his/her EK/ES. Since this study is limited to knowing the time perspective of the students, it would be great if future researchers on STEM students would embark on this. Nonetheless, based on the significant correlation result between ES and immediate/future orientation, it is recommended that different sectors who are aiming at increasing the $\mathrm{FO}$ of individuals to work on the students' ES; likewise, FO can also be used as a platform to increasing the student' ES since they are related. Interestingly, EA\&B was found to be positively correlated to immediate orientation, and inversely correlated to future orientation. This suggested that a student with high EA\&B might be inclined more to his/her immediate needs, and a student with low EA\&B might be inclined to his/her distant needs. EA\&B has always been challenging to explain as it veers against the expectation because of having significant, negative, and weak correlations between distant orientation and among ELOC dimensions. While it might be true for other individuals to become more inclined to futureoriented thinking (FO) as their pro-environmental attitudes and behavior (EA\&B) increase (Carmi \& Arnon, 2014), based on the subject of this study, it tells otherwise. Hence, it can be gleaned from the results that developing STEM students' distant orientation may unlikely cultivate their proenvironmental attitudes and behavior. Zimbardo and Boyd's (1999) claim of developing a future-oriented community yields a positive result, may not be applicable in terms of improving the STEM students' EA\&B. Carmi's (2012) study about FO may shed light 
on this inverse relationship between EA\&B and FO. She pointed out that FO skills do not necessarily lead to pro-environmental attitudes and behavior, as humans always tend to seek social approval and conform to personal and social norms. She further explained that FO works best in correspondence with the environment only if a person deemed it personal and beneficial to his/her own good. Looking closely at the CFC Scale and Part 2 of the ELT, which measures the EA\&B of the students, it is apparent that CFC Scale can be perceived to be more personal than Part 2 of ELT (e.g., I consider how things might be in the future, and try to influence those things with my day to day behavior (CFC); I tighten faucets in public toilets when I see water dripping (EA\&B). They might have considered EA\&B less personal as this tackled about the environment which does not have an immediate effect on them. Thus, it is a challenge for environmental education to develop FO skills as one of its dimensions, while instilling pro-environmental behavior and attitude following people's personal motivations. Hence, to promote pro-environmental attitudes and behavior in accordance with futureoriented thinking, it would be helpful if the motivations instilled among the students are intrinsic as they are likely to be more effective (Deci \& Ryan, 2010; De Dominicis et., 2017).

\section{CONCLUSION AND RECOMMENDATION}

STEM students believed that they could best create environmental impacts through their recycling attitudes yet least by advocating on the environment. Moreover, it can be concluded that STEM students were more inclined to consider distant outcomes or consequences of their actions rather than focusing on their immediate needs. Meanwhile, their environmental literacy was below the passing rate. Positive and negative correlations were also established between the environmental literacy components (Environmental Knowledge, Environmental Attitudes and Behavior, Environmental Skills) and the Advocate dimension, and between the environmental literacy components and the immediate orientation. The Distant Orientation was positively correlated to Environmental Skills, but it was negatively correlated to the Environmental Attitudes and Behavior. Moreover, gender had significant effects on the Environmental Knowledge and the two dimensions of the internal environmental locus of control (Advocate and Recycling attitudes), but it did not affect both the immediate and distance orientation of the students. The ideal expected results are the positive relationships obtained among the interrelationships of the components of environmental literacy and the environmental locus of control. The negative relationships revealed in the study are deviations from the most extant research previously mentioned. Hence, it is hoped that more studies would embark on these areas to deepen the analysis and to contribute to the growing knowledge of environmental literacy, environmental locus of control, and future orientation.

It is necessary, therefore, to recommend to different sectors to continuously evaluate the effectiveness of their teaching approaches, environmental campaigns, environmental initiatives, and/or environmental policies to keep pace with the changing human behavior - usually motivated and dictated by different factors but mostly on a personal basis. Different stakeholders should also work handin-hand in exerting more effort to improve the environmental literacy of STEM students in the Philippines. During this COVID-19 pandemic when the academe faces many challenges in lesson delivery, it is hoped that environmental knowledge being the antecedent to environmental behavior should not be neglected; and though lessons are mostly done online, it is suggested that ample opportunities should still be given to students to develop their environmental attitudes and behavior through insightful curriculum materials. Teachers might need to go beyond environmental theories and engage students in authentic experiences to provide them with active roles in learning environmental topics. These topics should not only be consistently integrated among the fields of sciences, but also in other subjects making them interdisciplinary, meaningful, and relatable.

\section{REFERENCES}

Alp, E., Ertepinar, H., Tekkaya, C., \& Yilmaz, A. (2008). A statistical analysis of children's environmental knowledge and attitudes in Turkey. Journal International Research in Geographical and Environmental Education, 15(3), 210-223. http://dx.doi.org/10.2167/irgee193.0

Atewe, A., \& Aloka, J. P. (2018). Influence of internal locus of control on mathematics achievement among students in secondary schools in Kenya. International Journal of Education and Research, 6(8), 153-162.

http://www.ijern.com/journal/2018/August2018/13.pdf

Atibuni, D. Z., Ssenyonga, J., Olema, D. K., \& Kemeza, I. (2017). Locus of control as a predictor of academic attitudes among university students. International Journal of Educational Policy Research and Review, 4(6), 125-137.

https://doi.org/10.15739/IJEPRR.17.014

Balderjahn, I. (1988). Personality variables and environmental attitudes as predictors of 
ecologically responsible consumption patterns. Journal of Business Research, 17(1), 51-56. https://doi.org/10.1016/0148-2963(88)90022-7

Boquet, Y. (2017). The Philippine archipelago. Springer Geography. https://doi.org/10.1007/978-3-31951926-5_15

Brooks, M., \& Hounshell, P. B. (1975). A study of locus of control and science achievement. Journal of Research in Science Teaching, 12(2), 175-181. https://doi.org/10.1002/tea.3660120212

Calsado, C. F. (2013). Students' personal demographics, cognitive styles, values, and decision making in environmental education. University of the Philippines.

Cannon, J. R., \& Scharmann, L. C. (1996). Influence of a cooperative early field experience on preservice elementary teachers' science self-efficacy. Science Teacher Education, 80(4), 419-436.

https://doi.org/10.1002/(SICI)1098237X(199607)80:4<419::AID-SCE3>3.0.CO;2-G

Carmi, N. (2012). Caring about tomorrow: Future orientation, environmental attitudes and behaviors. Environmental Education Research, 19(4), 430444. https://doi.org/10.1080/13504622.2012.700697

Carmi, N., \& Arnon, S. (2014). The role of future orientation in environmental behavior: Analyzing the relationship on the individual and cultural levels. Society and Natural Resources, 27(12), 1304-1320. https://doi.org/10.1080/08941920.2014.928393.

Chapman, D \& Sharma, K. (2002). Environmental attitudes and behavior of primary and secondary students in Asian cities: An overview strategy for implementing an Eco-schools programme. The Environmentalist, 21(4), 265-272. https://doi.org/10.1023/A:1012996016601.

Chmielewski, J., Kusztal, P., \& Zeber-Dzikowska, I. (2018). Anthropogenic impact on the environment (case study). The Journal of Institute of Environmental Protection-National Research Institute, 29(1), 30-37. https://doi.org/10.2478/oszn-2018-0006

Cimpian, J. R., Kim, T. H., \& McDermott, Z. T. (2020). Understanding persistent gender gaps in STEM. Science, 368(6497), 1317-1319. https://doi.org/10.1126/science.aba7377

Cleveland, M., Kalamas, M., \& Laroche, M. (2005). Shades of green: Linking environmental locus of control and pro-environmental behaviors. Journal of Consumer Marketing, 22(4), 198-212. https://doi.org/10.1108/07363760510605317

Cleveland, M., Kalamas, M., \& Laroche, M. (2012). "It's not easy being green": Exploring green creeds, green deeds, and internal environmental locus of control. Psychology \& Marketing, 29(5), 293-305. https://doi.org/10.1002/mar.20522

Congress of the Philippines. (2008). Republic Act No. 9512: An Act to Promote Environmental Awareness through Environmental Education and for Other Purposes. Retrieved from The Law Phil Project: https://www.lawphil.net/statutes/repacts/ra2008 /ra_9512_2008.html

Connell, D. (2009). Planning and its orientation to the future. International Planning Studies, 14(1), 85-89. https://doi.org/10.1080/13563470902741609

Contreras, R. C., Catamin, R. D., Ciasico, M. C., \& Cataluňa, M. P. (2015). Environmental literacy, concern and disaster preparedness among residents in municipality of Calinog, Western Visayas Region, Philippines. Multidisciplinary Research Journal, 3.

Corral-Verdugo, V., Fraijo-Sing, B., \& Pinheiro, J. Q. (2006). Sustainable behavior and time perspective: Present, past, and future orientations and their relationship with water conservation behavior. Revista Interamericana de Psicología, 40(2), 139-147.

Coyle, K. (2005). Environmental literacy in America. Washington, DC: The National Environmental Education \& Training Foundation.

Deci, E. L., \& Ryan, R. M. (2010). Intrinsic motivation. Retrieved from Wiley Online Library: https://onlinelibrary.wiley.com/doi/full/10.1002/ 9780470479216.corpsy0467

De Dominicis, S. D., Schultz, P. W., \& Bonaiuto, M. (2017). Protecting the environment for selfinterested reasons: Altruism is not the only pathway to sustainability. Frontiers in Psychology. https://doi.org/10.3389/fpsyg.2017.01065

Department of Environment and Natural Resources. (2018). Saving boracay. Retrieved July 2018, from Department of Environment and Natural Resources: https://www.denr.gov.ph/news-andfeatures/features/4303-saving-boracay.html

DepEd. (2012). K to 12 basic education curriculum. Retrieved May 2018, from Department of Education: http://www.deped.gov.ph/k-to-12/beccgs/als-program

DepEd. (2015). Policy guidelines on classroom assessment for the $\mathrm{k}$ to 12 basic education program. Retrieved from Gov.ph: https://www.deped.gov.ph/wpcontent/uploads/2015/04/D0_s2015_08.pdf

DepEd. (2016). Deped.gov.ph. Retrieved from K to 12 Curriculum Guide Science: https://www.deped.gov.ph/wpcontent/uploads/2019/01/Science-CG_withtagged-sci-equipment_revised.pdf

Diekmann, A., \& Preisendörfer, P. (2003). Green and greenback: The behavioral effects of environmental attitudes in low-cost and high-cost situations. Rationality and Society, 14(4), 441-472. https://doi.org/10.1177/1043463103154002

Ebreo, A., \& Vining, J. (2001). How similar are recycling and waste reduction? Environment and Behavior, 33(3), 424- 
448. https://doi.org/10.1177/0013916012197306 1

Eddy, S. L., Brownell, S. E., \& Wenderoth, M. P. (2017). Gender gaps in achievement and participation in multiple introductory biology classrooms. Life Sciences Education, 13, 478-492. https://doi.org/10.1187/cbe.13-10-0204

Eisler, A., Eisler, H., \& Yoshida, M. (2003). Perception of human ecology: Cross-cultural and gender comparisons. Journal of Environmental Psychology, 23(1), 89-101. https://doi.org/10.1016/S02724944(02)00083-X

Environmental Performance Index. (2020). 2020 Environmental performance index. New Haven: Yale Center for Environmental Law \& Policy

European Environment Agency. (2016). Unsustainable consumption - the mother of all environmental issues? Retrieved from https://www.eea.europa.eu/highlights/unsustaina ble-consumption-2013-the-mother

Estonanto, A. J.J. (2017). Acceptability and difficulty of the STEM track implementation in senior high school. Asia Pacific Journal of Multidisciplinary Research, 5(2), 43-50.

Flores, J. A., Caqueo-Urízar, Alejandra, Ramirez, C., Arancio, G., \& Cofre, J. P. (2020). Locus of control, self-control, and gender as predictors of internalizing and externalizing problems in children and adolescents in northern Chile. Educational Psychology, https://doi.org/10.3389/fpsyg.2020.02015

Ferguson J.M., Higgins L.F. (2015). Structure and locus of control in marketing courses. In: Hawes J.M., Glisan G.B. (eds) Proceedings of the 1987 Academy of Marketing Science (AMS) Annual Conference. Developments in Marketing Science: Proceedings of the Academy of Marketing Science.

Garcia, M. N., \& Cobar-Garcia. (2016). The environmental literacy of elementary school teachers based in the city Of Manila and Nueva Ecija Province. Journal of Nature Studies 17(2), 10-29.

Garcia, V. P. (2013). ABS-CBN News. Retrieved June 2019, from How a Pinay garbage collector became a millionaire: https://news.abscbn.com/focus/07/24/13/how-pinay-garbagecollector-became-millionaire

GMA Network. (2016). Youtube.com. Retrieved from Investigative Documentaries: 6 taong gulang na bata, nangangalakal sa ilog ng basura para kumita: https://www.youtube.com/watch?v=71GM5pUD6 vI

Giefer, M. M., Peterson, M. N., \& Chen, X. (2019). Interactions among locus of control, environmental attitudes and pro-environmental behaviour in China. Environmental Conservation, 234-240. https://doi.org/10.1017/S0376892919000043

Greene, B., \& DeBacker, T. (2004). Gender and orientations toward the future: links to motivation. Educational Psychology Review, 16(2), 91-120.
https://doi.org/10.1023/B:EDPR.0000026608.506 11.b4

Griffin, D. P. (2014). Locus of control and psychological well-being: Separating the measurement of internal and external constructs -- A pilot study. EKU Libraries Research Award for Undergraduates. 2. http://encompass.eku.edu/ugra/2014/2014/2

Hannafin, M. J. (1984). Guidelines for using locus of instructional control in the design of computerassisted Instruction. Journal of instructional development, $7(6)$. https://doi.org/10.1007/BF02905753

Haurdy, D. L. (1988). Evidence that science locus of control orientation can be modified through instruction. Journal of Research in Science Teaching, 25(3), 233-246.

https://doi.org/10.1002/tea.3660250308

Haudry, D. L. (1989). The contribution of science locus of control orientation to expressions of attitude toward science teaching. Journal of Research in Science Teaching, 26(6), 503-517. https://doi.org/10.1002/tea.3660260603

Hayes, B. C. (2001). Gender, scientific knowledge, and attitudes toward the environment: A cross-national analysis. Political Research Quarterly, 53(3), 657671. https://doi.org/10.2307/449275

Hazari, Z., Tai, R. H., \& Sadler, P. M. (2007). Gender differences in introductory university physics performance: The influence of high school physics preparation and affective factors. Science Education, 91, 847-876. https://doi.org/10.1002/sce.20223

Hollweg, K., Taylor, J., Bybee, R., Marcinkowski, T., McBeth, W., \& Zoido, P. (2011). Developing a framework for assessing environmental literacy. Retrieved June 2018, from North American Association for Environmental Education: https://cdn.naaee.org/sites/default/files/devframe wkassessenvlitonlineed.pdf

Honora, D. (2002). The relationship of gender and achievement to future outlook among African American adolescents. Adolescence, 37(146), 301316.

Honora, D. T. (2007). Time perspective and school membership as correlates to academic achievement among African American adolescents. Retrieved from National Library of Medicine. https://pubmed.ncbi.nlm.nih.gov/18047236/

Johnson, S. L., Blum, R., \& Cheng, T. (2014). Future orientation: A construct with implications for adolescent health and wellbeing. International Journal of Adolescent Medical Health, 26(4), 459468. https://doi.org/10.1515/ijamh-2013-0333

Joireman, J. (2005). Environmental problems as social dilemmas. In A. Strathman, \& J. Joireman, Understanding Behavior in the Context of Time (pp. 289-304). New Jersey: Lawrence Erlbaum Associates. 
Joireman, J., Lasane, T. P., Bennett, J., Richards, D., \& Solaimani, S. (2001). Integrating social value orientation and the consideration of future consequences within the extended norm activation model of proenvironmental behaviour. British Journal of Social Psychology, 40(1), 133-155. http://dx.doi.org/10.1348/014466601164731

Joireman, J, Van Lange, P., \& Van Vugt, M. (2003). Who cares about the environmental impact of cars? Those with an eye toward the future. Environment and Behavior, 35(X), 1-20. https://doi.org/10.1177/0013916503251476

Katsuno, C., Gregorio, E. R., Lomboy, M. F., Nonaka, D., Hernandez, P. M., Estrada, C. A., Kobayashi, J. (2019). Quality of public school toilets and the frequency of changing sanitary napkins among students in public secondary schools in the City of Manila, Philippines. Tropical Medicine and Health, 5, https://doi.org/10.1186/s41182-018-0131-8

Kennedy-Moore, E., \& Watson, J. C. (1999). Emotions and social behavior.Expressing emotion: Myths, realities, and therapeutic strategies. Guilford Press

Kollmuss, A., \& Agyeman, J. (2002). Mind the gap: Why do people act environmentally and what are the barriers to pro-environmental behavior? Environmental Education Research, 8(3), 239-260. https://doi.org/10.1080/13504620220145401

Korb, K. A. (2012). Conducting educational research. Retrieved from Adopting or Adapting an Instrument: http://korbedpsych.com/R09aAdopt.html\#: :text $=\mathrm{In} \% 20$ general $\% 2 \mathrm{C} \% 20$ adopting $\% 20$ (using $\% 20 \mathrm{v}$ erbatim,have $\% 20$ to $\% 20$ collect $\% 20$ validity $\% 20$ evi dence.

Latif, S. A., Omar, M. S., Bidin, Y. H., \& Awang, Z. (2013). Role of environmental knowledge in creating proenvironmental residents. Procedia Social and Behavioral Sciences, 105, 866-874. https://doi.org/10.1016/j.sbspro.2013.11.088

Laureiro-Martinez D., Trujillo C. A., \& Unda, J. (2017). Time perspective and age: A review of age associated differences. Frontiers in Psychology. 8(101). https://doi.org/10.3389/fpsyg.2017.0010 1

Liang, S.-W., Fang, W.-T., Yeh, S.-C., Lui, S.-Y., Tsai, H.-M., Chou, J.-Y., \& Ng, E. (2018). A nationwide survey evaluating the environmental literacy of undergraduate students in Taiwan. Sustainability, 10(6), 1730. https://doi.org/10.3390/su10061730

Li, J., Li, M., Wang, J., Li, J., Su, H., \& Maoxing, H. (2014). Report on global environmental competitivenes. Retrieved from Global Environmental Issues and Human Wellbeing: https://link.springer.com/chapter/10.1007/978-3642-54678-5_1

Lopez, C. S. (1997). General and science loci of control as influenced by selected factors and as predictors of science attitude and achievement. University of the Philippines College of Education.
Luckenbill-Edds, L. (2002). The educational pipeline for women in biology: No longer leaking? BioScience, 52(6), 513-521.

https://doi.org/10.1641/00063568(2002)052[0513:TEPFWI]2.0.C0;2

Marcinkowski, T. (2010). Contemporary challenges and opportunities in environmental education: Where are we headed and what deserves our attention? The Journal of Environmental Education, 41(1), 34-54. https://doi.org/10.1080/00958960903210015

Marten, G. (2001). Human ecology - basic concepts for sustainable development. London: Earthscan Publications.

McCarty, J. A., \& Shrum, L. J. (2001). The influence of individualism, collectivism, and locus of control on environmental beliefs and behavior. Journal of Public Policy \& Marketing, 20(1), 93-104. https://doi.org/10.1509/jppm.20.1.93.17291

McCright, A. (2010). The effects of gender on climate change knowledge and concern in the American public. Population and Environment, 32. 66-87. https://doi.org/10.1007/s11111-010-0113-1.

Meinck, S., \& Brese, F. (2019). Trends in gender gaps: using 20 years of evidence from TIMSS. Large-Scale Assessments in Education, 7(8). https://doi.org/10.1186/s40536-019-0076-3

Mello, Z. R., \& Worrell, F. C. (2006). The relationship of time perspective to age, gender, and academic achievement among academically talented adolescents. Journal for the Education of the Gifted, 29(3), 271-289. https://doi.org/10.1177/016235320602900302

Mohd Khir, A., \& Redzuan, M. (2017). Locus of control, future orientation, and academic achievement among Orang Asli Adolescents in Malaysia. Retrieved April 25, 2019, from https://www.researchgate.net/publication/319482 306_Locus_of_Control_Future_Orientation_and_Aca demic_Achievement_among_Orang_Asli_Adolescent s_in_Malaysia

National Economic and Development Authority. (2017). Philippine development plan 2017-2022. Pasig City: National Economic and Development Authority. Retrieved January 20, 2019, from http://pdp.neda.gov.ph/wpcontent/uploads/2017/01/PDP-2017-2022-07-202017.pdf

National Geographic. (n.d.). Human impacts on the environment. Retrieved January 12, 2019, from National Geographic:

https://www.nationalgeographic.org/topics/resour ce-library-human-impactsenvironment $/$ ? $=$ \&page $=1$ \&per_page $=25$

Nunez, M. B., \& Clores, M. A. (2017). Environmental literacy of K-10 student completers. International Journal of Environmental \& Science Education, 10(5), 1195-1215. 
OECD. (2012). How "green" are today's 15-year-olds? Retrieved September 2018, from PISA in Focus: https://www.oecd.org/pisa/pisaproducts/pisainfo cus/50150271.pdf

OECD. (2020). Gender and environmental statistics: Exploring available data and developing new evidence. Retrieved from OECD.org: http://www.oecd.org/environment/brochuregender-and-environmental-statistics.pdf

Official Gazette, (n.d.). What is K to 12 Program? Retrieved May 6, 2019, from Gov.ph: https://www.officialgazette.gov.ph/k-12/

Oliva, M. (2013). Environmental literacy among urban college students: Barriers and enabling forces. University of the Philippines.

Prenda, K. M., \& Lachman, M. E. (2001). Planning for the future: A life management strategy for increasing control and life satisfaction in adulthood. Psychology and Aging, 16(2), 206-216. http://dx.doi.org/10.1037/0882-7974.16.2.206

Ritchie, H. (2018). Plastic Pollution. Retrieved from Our World in Data:

https://ourworldindata.org/plasticpollution\#citation

Rotter, J. (1966). Generalized expectancies for internal versus external control of reinforcements. Psychological Monographs, Whole No. 609.

Sanford, C. (1985). Revision of the perceived environmental control measure. University of Wisconsin-Stevens Point, College of Natural Resources. http://digital.library.wisc.edu/1793/80116

Sherman, A. C., Higgs, G. E., \& Williams, R. L. (2007). Gender differences in the locus of control construct. Psychology \& Health, 239-248. https://doi.org/10.1080/08870449708407402

Smith, C., \& Watson, J. (2018). STEM: Silver Bullet for a viable future or just more flatland? Journal of Futures Studies, 18(4), 25-44. https://doi.org/10.6531/JFS.201806.22(4).0003

Smith-Sebasto, N.J \& Fortner, Rosanne W. (2010). The environmental action internal control index. The Journal of Environmental Education, 25(4), 23-29. https://doi.org/10.1080/00958964.1994.9941961

Stockholm Resilience Centre. (n.d.). The nine planetary boundaries. Retrieved from Stockholm Resilience Centre : https://www.stockholmresilience.org/research/pla netary-boundaries/planetary-boundaries/aboutthe-research/the-nine-planetary-boundaries.html Strathman, A., Gleicher, F., Boninger, D. S., \& Edwards, C. S. (1994). The consideration of future consequences: Weighing immediate and distant outcomes of behaviour. Journal of Personality and Social Psychology, 66(4), 742-752. https://doi.org/10.1037/0022-3514.66.4.742

Taber, K. S. (2017). The use of Cronbach's alpha when developing and reporting research instruments in science education. Research in Science Education,
48(6), 1273-1296.

https://doi.org/10.1007/s11165-016-9602-2

UNESCO. (1978). Declaration of recommendations. Intergovernmental Conference on Environmental Education, (p. 38). Paris.

UNESCO. (1997). Declaration on the responsibilities of the present generations towards future generations. Retrieved from UNESCO portal: http://portal.unesco.org/en/ev.php-

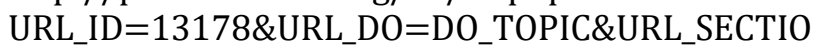
$\mathrm{N}=201 . \mathrm{html}$

UNESCO. (2017). Cracking the code: girls' and women's education in science, technology, engineering and mathematics (STEM). Paris: UNESCO.

United Nations. (2015). Resolution adopted by the general assembly on 25 September 2015. Transforming our world: the 2030 Agenda for Sustainable Developmen. Sustainable Development Goals Knowledge Platform.

USAID. (2019). Environment. Retrieved from USAID: https://www.usaid.gov/philippines/energy-andenvironment

Venter, 0. (2016). Population growth outpaces human ecological footprint. Retrieved May 2018, from University of British Columbia: https://www.unbc.ca/releases/40955/populationgrowth-outpaces-human-ecological-footprint

Vicente-Molina, M., Fernandez-Sainz, A., \& IzagirreOlaizola, J. (2018). Does gender make a difference in pro-environmental behavior? The case of the Basque Country University students. Journal of Cleaner Production, 176, 89-98. https://doi.org/10.1016/j.jclepro.2017.12.079

Wang, D. (2005). Students' learning and locus of control in web-supplemental instruction. Innovative Higher Education. 30(1), 60-67.

https://doi.org/10.1007/s10755-005-3299-x

Weimer, K., Ahlström, R., Lisspers, J., \& Lipsanen, J. (2017). Values, attitudes, moral judgment competence, locus of control and sense of coherence as determinants of proenvironmental behaviors and behavioral intentions. Journal of Multidisciplinary Engineering Science and Technology (JMEST), 4(5), 2568-2583.

Williams, R. D. (2017). An Assessment of Environmental Literacy Among Oklahoma Public High School Students and the Factors Affecting Students' Environmental Literacy. Retrieved from Harvard Library Office for Scholarly Communication: https://dash.harvard.edu/handle/1/33826276

World Economic Forum. (2017). The Global Gender Gap Report 2017. Retrieved from World Economic Forum: https://www3.weforum.org/docs/WEF_GGGR_201 7.pdf

Wu, E., Cheng, J.-Q., \& Zhang, J.-B. (2020). Study on the environmental education demand and environmental literacy assessment of citizens in 
sustainable urban construction in Beijing.

Sustainability, 12(1), 241.

https://doi.org/10.3390/su12010241

Xiao, C., \& Hong, D. (2016). Gender differences in concerns for the environment among the Chinese Public: An update. Society \& Natural Resources, https://doi.org/10.1080/08941920.2016.1238986.

Xiao, C., \& McCright, A. M. (2013). Gender differences in environmental concern: Revisiting the institutional trust hypothesis in the USA. Environment and Behavior,47(1), 17-37. https://doi.org/10.1177/0013916513491571

Yumusak, A., Sargin, S. A., Baltaci, F., \& Kehlani, R. R. (2016). Science and mathematics teacher candidates' environmental knowledge, awareness, behavior and attitudes. International Journal of Environmental \& Science Education, 11(6), 13371346.

Zimbardo, P. \& Boyd, J. (1999). Putting time in perspective: A valid, reliable individual-differences metric. Journal of Personality and Social Psychology, 77(6), 1271-1288.

https://doi.org/10.1037/0022-3514.77.6.1271 